\title{
Tricuspid valve regurgitation in heart transplant patients
}

\section{(1DBoško Skorić*}

University of Zagreb School of Medicine, University Hospital Centre Zagreb, Zagreb, Croatia
KEYWORDS: tricuspid valve regurgitation, heart transplantation.

CITATION: Cardiol Croat. 2018;13(5-6):201. | https://doi.org/10.15836/ccar2018.201

*ADDRESS FOR CORRESPONDENCE: Boško Skorić, Klinički bolnički centar Zagreb, Kišpatićeva 12, HR-10000 Zagreb, Croatia. / E-mail: bskoric3@yahoo.com

ORCID: Boško Skorić, https://orcid.org/0000-0001-5979-2346

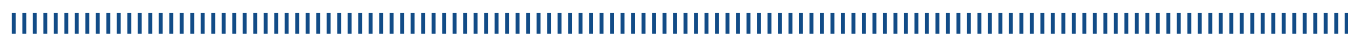

Tricuspid valve regurgitation is the most frequent valve disease after heart transplantation (HTx) ${ }^{1}$. Post-transplant tricuspid valve regurgitation ranges in different severity but the majority are of no clinical importance. There are many causes of tricuspid valve regurgitation and they are related to the time of diagnosis after the surgery. In the early post-transplant period, tricuspid valve regurgitation is usually secondary to pulmonary hypertension, i.e. increased pulmonary vascular resistance. Most of tricuspid valve regurgitation in the late phase is secondary to tricuspid annulus enlargement due to right ventricular remodeling and dilatation ${ }^{2}$. Other frequent causes are lesions of valve apparatus during right ventricular endomyocardial biopsy, acute graft rejection and the alteration of right atrial morphology due to the surgical technique.

Medical management of clinically significant tricuspid valve regurgitation in heart transplant patients is the standard therapy. Surgical correction is indicated in properly selected patients who are refractory to medical treatment alone.
RECEIVED:

May 3, 2018

ACCEPTED:

May 10, 2018

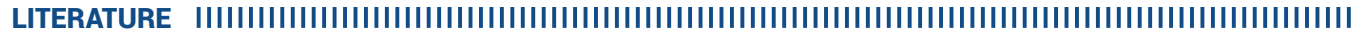

1. Kwon MH, Shemin RJ. Tricuspid valve regurgitation after heart transplantation. Ann Cardiothorac Surg. 2017 May;6(3):270-274. https://doi.org/10.21037/acs.2017.04.02

2. Berger $Y$, Har Zahav Y, Kassif Y, Kogan A, Kuperstein R, Freimark D, et al. Tricuspid valve regurgitation after orthotopic heart transplantation: prevalence and etiology. J Transplant. 2012;2012:120702. https://doi.org/10.1155/2012/120702
Cardiologia Croatica $\square$ 2018;13(5-6):201. 